\title{
Influence of Product Quality, Service Quality and Completeness on Customer Satisfaction on Mie Soponyono Producer
}

\author{
Mamduhan Zakirin \\ Universitas Ciputra Surabaya \\ mamduhanzakirin@gmail.com \\ https://doi.org/10.37715/rmbe.v1i2.2434
}

\begin{abstract}
Mie Soponyono Manufacturer is a company engaged in the food and beverage sector, which is precisely producing wet noodles and dumpling skin. The purpose of this study was to see the effect of product influence, service quality and completeness on customer satisfaction. The population in this study were subscribers of the Mie Soponyono producers. Determination of the sample in this study using purposive sampling. This study uses multiple linear regression analysis. The results of this study indicate that product quality has no effect on customer satisfaction, service quality affects customer satisfaction and product completeness affects customer satisfaction. Variables of product quality, service quality, and product completeness contributed to customer satisfaction by $70 \%$, while the rest could be built by other variables.
\end{abstract}

Keywords - Product Quality, Service Quality, Product Completeness, Customer Satisfaction, Sopnyono Noodle Manufacturer

\section{Introduction}

Competition in the business that is happening today is increasingly competitive, these conditions make companies must have an advantage in order to win the competition, one way is to fulfill consumer desires. So, the way to maintain the market is to make consumers satisfied, including by providing the best product quality and service quality (Anshori \& Langner, 2007, p. 18; Kotler \& Armstrong, 2010, pp. 20-23). One of the companies engaged in the food sector is Mie Soponyono Manufacturer. This company produces noodles and dumpling skins located in Surabaya. Culinary businesses in general have several factors that need to be considered, the main thing is the quality of the product, the two benefits of the product, and no less important is how the service is provided by producers to consumers when they will make a purchase of these culinary products. The results of initial interviews with five consumers of Mie Soponyono Producers showed that product quality, service, completeness and long queues were the reasons that many respondents expressed. While the respondent's answer if it is cheaper to move elsewhere or not, four respondents answered no with reasons because they are already customers, are familiar with the employees and the queue time is not long, while one respondent answered that if the price is not much different, they will not move because they want to spend all the time.

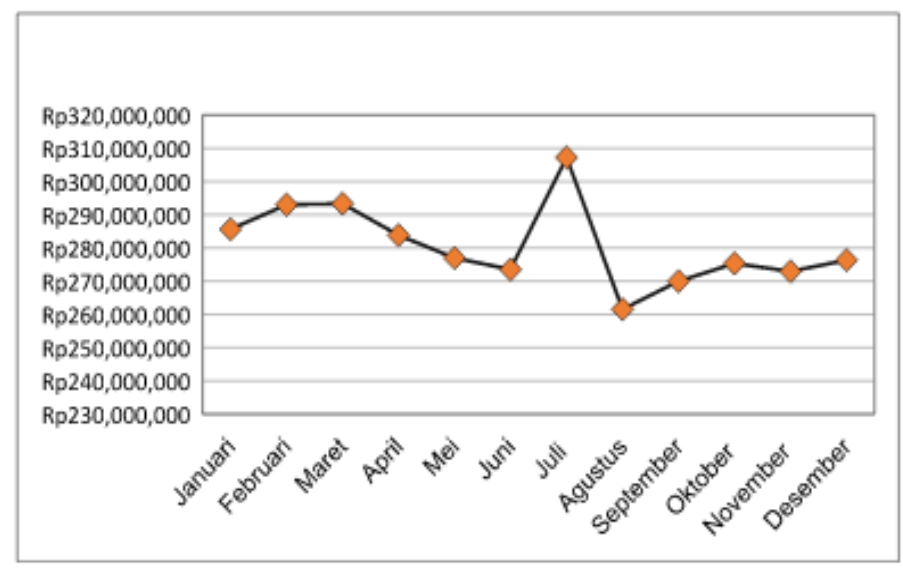

Graph 1.1 Graph of Sales Turnover of Mie Soponyono Producers in 2019

The graph above shows that turnover in the 2019 period tended to stagnate but fell slightly. However, in July there was a drastic increase and in the following month it fell sharply. The sharp increase and decrease that occurred in July and August was caused by the Idul Fitri holiday in that month because the Mie Soponyono Producer 
was on holiday for four days so that consumers made purchases in large quantities with the aim of stocking up during the holiday production period. The increasing intensity of business competition in the food sector requires companies to always pay attention to the needs and desires of consumers and try to meet consumer expectations by providing more satisfying services than competitors. Companies must be able to win the competition, especially in terms of providing satisfaction to consumers which later can provide benefits to the company, among others, namely the relationship between companies and consumers to be harmonious, creating loyalty to consumers and also forming a word of mouth recommendation (Fandy Tjiptono, 2008, p. 24). That's why only companies that have quality can compete and dominate the market (Atmawati \& Wahyuddin, 2004). Thus, this research is entitled "The effect of product quality, service quality and completeness on customer satisfaction in Mie Soponyono Producers".

\section{Literature Review}

2.1. Previous Research

Research conducted by Pertiwi (2017) entitled "The Effect Of Product Quality, Completeness Of Product and Service Quality to Customer Satisfaction "Yulia Bakery" Kota Kediri". The results of the study can be concluded that (1) product quality partially (individually) has a significant effect on consumer satisfaction, (2) product completeness partially (individually) has a significant effect on consumer satisfaction, (3) product quality partially (individual) has a significant effect on consumer satisfaction, (4) product quality, product completeness, service quality simultaneously (together) have a significant effect on consumer satisfaction.

Research conducted by Nur Prabowo (Nur Prabowo, 2015) entitled "Pengaruh Harga, Promosi, Lokasi, Kelengkapan Produk Dan Kualitas Pelayanan Terhadap Kepuasan Konsumen (Studi Empiris pada Konsumen Indomaret di Kabupaten Karanganyar)". The results of regression analysis, the independent variables that have the most influence on the dependent variable are price, promotion, location, product completeness, and service quality. The results of the $t$ test prove that all independent variables (price, promotion, location, product completeness, service quality) have a positive effect on the dependent variable, namely Indomaret consumer satisfaction in Karanganyar Regency.

Research conducted by Mulyono et al. (2007) entitled "Analisis pengaruh kualitas produk dan kualitas layanan terhadap kepuasan konsumen (Studi kasus pada Perumahan Puri Mediterania Semarang)". The purpose of this study was to examine the effect of product quality and service quality on consumer satisfaction. The results showed that product quality and service quality had a positive and significant effect on consumer satisfaction. Product quality is the most important variable in influencing consumer satisfaction than service quality.

\subsection{Theoretical basis}

\subsubsection{Product quality}

According to Tjiptono (2008), quality reflects all dimensions of product offerings that generate benefits for customers. Dimensions of product quality according to Tjiptono (2008) are:

1. Performance (performance), relates to the basic operating characteristics of a product.

2. Durability (durability), which means how long or the age of the product in question lasts before the product must be replaced. The greater the frequency of consumer use of the product, the greater the power of the product.

3. Conformance to specifications, namely the extent to which the basic operating characteristics of a product meet certain specifications from consumers or no defects are found in the product.

4. Features are product characteristics designed to enhance product functions or increase consumer interest in the product.

5. Reliability (reliability) is the probability that the product will work satisfactorily or not within a certain period of time. The less chance of damage, the more reliable the product is.

6. Aesthetics (aesthetics), relates to how the product looks.

7. Perceived quality is the result of using indirect measurements because there is a possibility that consumers do not understand or lack information about the product in question.

8. Service ability, including speed and ease of repair, as well as the competence and friendliness of service staff. 


\subsubsection{Service quality}

According to Kotler and Keller (2012), the word "service", "service", or also known as "service", is any action or performance that one party can offer to another, which is essentially intangible and does not result in the ownership of anything. Service quality is the overall characteristics and characteristics of a product or service in terms of its ability to meet predetermined needs. If the service received or felt is in accordance with what is expected, then the quality is perceived as good and can satisfy the customer. Conversely, if what is received is lower than expected, then the quality is perceived as bad or unsatisfactory (Lupiyoadi, 2001, p. 144)

According to A. Parasuraman and Berry (1998, as cited in F. Tjiptono \& Chandra, 2011, pp. 174-175) there are five dimensions of service quality that are used as guidelines by customers in assessing service quality, namely:

1. Tangible the appearance of physical facilities, equipment, and personnel.

2. Empathy (Empathy) Requirements to care, give personal attention to customers.

3. Reliability (reliability) the ability to perform the promised services accurately and reliably.

4. Responsiveness (responsiveness) Willingness to help customers and provide services quickly or responsively.

5. Assurance Knowledge and courtesy of employees and their ability to generate trust and confidence.

As explained by Tjiptono (2009), the level of service quality (service) is a crucial aspect in the total service offering. Quality is one of the important factors used by consumers to evaluate the services of an organization.

\subsubsection{Product Accessories}

Kotler (Kotler, 2002, p. 448) states that a product is anything that can be offered to a market to satisfy a need or want. Product completeness is the activity of procuring goods that are in accordance with the business the store is running (food-based products, clothing, household goods, general products, etc. or a combination) to be provided in the store at the appropriate amount, time, and price. Factors that a shop considers in choose the products they sell, namely (Gilbert, 2003, p. 113):

1. Variety. Completeness of products sold can affect consumer considerations in choosing a store. 101 The Influence of Product Completeness and Service Quality on Purchase Decisions (Study on Supermarkets There is New in Salatiga City).

2. Width or Breath. Availability of complementary products from the main product offered. For example, in a bakery, apart from providing bread, they also provide a variety of drinks.

3. Depth. Kinds and types of characteristics of a product.

4. Consistency. Products that are in accordance with consumer desires must be maintained by maintaining the completeness, quality, and price of the products sold.

5. Balances. Closely related to the effort to adjust the type and variety

\subsubsection{Consumer Satisfaction}

According to Kotler and Armstrong (2016), consumer satisfaction is the level of one's feelings after comparing the perceived (performance or results) compared to their expectations. Tjiptono (2008) states that customer satisfaction is a post-purchase evaluation where the chosen alternative is at least equal to or exceeds expectations, while dissatisfaction arises when the results do not meet expectations. There are five main factors that must be considered by the company in determining the level of satisfaction consumers, namely:

1. Product quality. Consumers will be satisfied if their evaluation results show that the products they use are of high quality.

2. Service quality. Consumers will feel satisfied if they get good service or as expected.

3. Emotional. Consumers will feel proud and gain confidence that other people will be amazed by him when using a product with a certain brand which tends to have a higher level of satisfaction. The satisfaction obtained is not because of the quality of the product but the social value that makes consumers satisfied with a particular brand.

4. Price. Products that have the same quality but set a relatively cheap price will provide higher value to consumers. 


\section{Research Methods}

\subsection{Analysis Model}

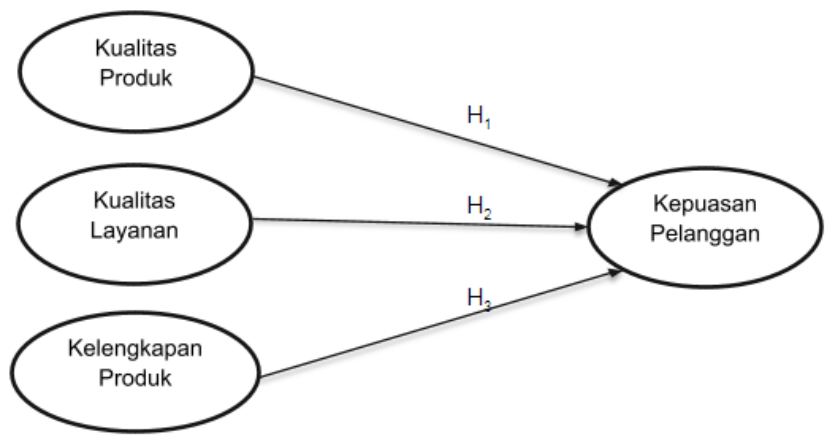

Figure 3.1. Data Analysis Model Source: Process Data (2020)

\subsection{Hypothesis}

Based on previous research and the theories above, the hypotheses of this study are:

1. $\mathrm{H}_{1}$ : Product quality has a significant effect on customer satisfaction

2. $\mathrm{H}_{2}$ : Service quality has a significant effect on customer satisfaction

3. $\mathrm{H}_{3}$ : Completeness of the product has a significant effect on customer satisfaction

\subsection{Research Approach}

Based on the problems raised, this research uses a quantitative approach. The location of this research was conducted on Jl. Wonokusumo 85a, Surabaya which is the location of the Mie Soponyono producer. The selected respondents are consumers who are in the Surabaya area. The time in this study was carried out for 2 months, starting from March 2020 to April 2020. The population in this study were consumers of Mie Soponyono Producers for the period March 2020 - April 2020. This study used purposive sampling as a sampling technique. The sample criteria used in this study were consumers who had shopped at least twice, as many as 112 respondents. The types of data used in this study are primary data and secondary data. The primary data used in this study were obtained from questionnaires filled out by respondents, namely the Mie Soponyono producer customers. The secondary data used in this study were obtained from various written sources such as journals, scientific writings, and publications from the internet related to research.

The method of data collection carried out in this study used a questionnaire technique. This questionnaire is used to find out data about product quality, service quality, and product completeness which will later be used to determine the level of satisfaction of respondents as consumers of Mie Soponyono Producers. In this study, the answers given by the respondents were then scored with reference to the Likert scale

Table 4.1 Likert scale

\begin{tabular}{|c|c|}
\hline Jawaban & Skor atau Nilai \\
\hline Sangat Setuju & 5 \\
\hline Setuju & 4 \\
\hline Ragu-ragu & 3 \\
\hline Tidak Setuju & 2 \\
\hline Sangat Tidak Setuju & 1 \\
\hline
\end{tabular}

\subsection{Data analysis}

Source: Ghozali, 2005

\subsubsection{Validity and Reliability Test}

According to Sunyoto (Sunyoto, 2009, p. 72), the validity test is used to measure whether or not a questionnaire is valid. The validity of the questionnaire is declared valid if the significance value is less than 0.05. reliability test shows the consistency and stability of a score. The reliability of the questionnaire is declared reliable if the Cronbach's Alpha value is greater than 0.6. 


\subsubsection{Classic assumption test}

1. Normality test is used to test the residual value generated normally distributed using the KolmogorovSmirnov method. If the significance value is $>0.05$, it is declared normally distributed (Priyatno, 2014, p. 94). This study also uses the Normal P-Plot method by looking at the spread along the diagonal line.

2. Multicollinearity test is used to test the correlation between independent variables in the regression model by looking at the variance inflation factor (VIF) and tolerance. To detect the absence of multicollinearity by looking at the value of tolerance it should not be $<0.1$ and the value of the variance inflation factor (VIF) $<$ 10 (Sujarweni, 2016).

3. Heteroscedasticity test is used to see the inequality of residual variance in the regression model using the Glejser method. If the significance value is $>0.05$, then it is stated that there is no heteroscedasticity (Priyatno, 2014, p. 115).

\subsubsection{Multiple Linear Regression Analysis}

\section{Description:}

$$
Y=\alpha+\beta_{1} X_{1}+\beta_{2} X_{2}+\beta_{3} X_{3}+e
$$

$$
\begin{aligned}
& \mathrm{Y}=\text { Customer Satisfaction } \\
& \alpha \quad=\text { Constant } \\
& \beta_{1}, \beta_{2}, \beta_{3} \quad=\text { Regression Coefficient } \\
& \mathrm{X}_{1} \quad=\text { Product Quality } \\
& \mathrm{X}_{2} \quad=\text { Quality of Service } \\
& \mathrm{X}_{3} \quad=\text { Product Completeness } \\
& e \quad=\text { Error }
\end{aligned}
$$

3.3.3. Hypothesis testing

1. Simultaneous Significance Test (F Test)

According to Siregar (2013) the simultaneous significance test ( $F$ test) is a simultaneous comparison of several population averages, if the value of Sig. F $<0.05$ means that the independent variables together have a significant effect on the dependent variable.

2. Partial Significance Test ( $\mathrm{t}$ Test)

According to Siregar (2013) the partial significance test ( $t$ test) is used to test the effect of the independent variable on the dependent variable partially. Value of Sig. $t$ is $<0.05$, which means that the independent variable individually or partially has a significant effect on the dependent variable

3. Coefficient of Determination Test $\left(\mathrm{R}^{2}\right)$ and Relationship Coefficient Test ( $\mathrm{r}$ )

According to Sugiyono (2012) the coefficient of determination is used to see the contribution of the independent and dependent variables with an $\mathrm{R}^{2}$ value between $0-1$. If the value is close to 1 , it means that the independent variable makes a greater contribution to predicting the variation of the dependent variable. According to Sugiyono (2012), the correlation coefficient is used to measure how much the relationship between the independent variable and the dependent variable is partially. If the value is close to 1 , then the relationship between the independent variable and the dependent variable is strong

\section{Result and Discussion}

\subsection{Overview of Research Objects}

In 1999 the Soponyono Factory again opened a new line of business which, according to Mr. Mujiono, is a unit in people selling food, namely the production of noodles and dumpling skins. Because most people who sell meatballs always go hand in hand with the sale of wonton noodles and Mr. Mujiono sees this as a new market potential, it has grown from initially selling only meatball selep services to developing and finally producing wonton noodles. Until now, the Mie Soponyono Factory already has 26 employees consisting of several sections, namely finance, managers, division heads, and manual workers. And now the Soponyono Factory has added a new line of business in 2019, namely Frozen Meatballs. 


\subsection{Respondent Profile}

The following is a description of respondents who meet the sample criteria, namely having purchased products from Mie Soponyono Manufacturers. The majority of respondents are male ( 88 respondents) and the rest are female (24). There are no respondents under the age of 20 years, there are 27 respondents aged 21 to 30 years, then there are 53 respondents aged 31 to 40 years, and 32 respondents aged over 40 years. It can be concluded that consumers of Mie Soponyono producers are dominated by male consumers and aged 31 to 40 years.

\subsection{Descriptive statistics}

Table 4.1. Mean Value and Standard Deviation of Product Quality

\begin{tabular}{|l|r|r|r|r|r|}
\hline \multicolumn{7}{|c|}{ Descriptive Statistics } \\
\hline & N & Minimum & Maximum & Mean & Std. Deviation \\
\hline X1_1 & 112 & 1 & 5 & 3,93 & 0,984 \\
\hline X1_2 & 112 & 1 & 5 & 3,64 & 1,030 \\
\hline X1_3 & 112 & 1 & 4 & 2,34 & 0,812 \\
X1_4 & 112 & 1 & 5 & 3,71 & 0,907 \\
\hline X1_5 & 112 & 1 & 5 & 3,54 & 0,848 \\
\hline X1 & 112 & & & 3,43 & 0,92 \\
\hline Valid N (listwise) & 112 & & & & \\
\hline \multicolumn{7}{|c|}{ Source: Data processed (2020) } \\
\hline
\end{tabular}

Table 4.1 shows that the highest mean value is 3.93, namely in the statement "this product is of high quality" while the lowest mean value is in the statement "attractive presentation level" which is 2.34 . Overall, the average value of respondents' answers on the product quality variable is 3.43 , so it can be said that most of the respondents agree on this variable.

Table 4.2. Mean Value and Standard Deviation of Service Quality

\begin{tabular}{|l|r|r|r|r|r|}
\hline \multicolumn{7}{|c|}{ Descriptive Statistics } \\
\hline & N & Minimum & Maximum & Mean & Std. Deviation \\
\hline X2_1 & 112 & 3 & 5 & 4,06 & 0,739 \\
\hline X2_2 & 112 & 3 & 5 & 4,26 & 0,707 \\
\hline X2_3 & 112 & 4 & 5 & 4,36 & 0,481 \\
\hline X2_4 & 112 & 3 & 5 & 4,11 & 0,787 \\
\hline X2_5 & 112 & 2 & 5 & 3,90 & 0,794 \\
\hline X2_6 & 112 & 2 & 5 & 3,88 & 0,712 \\
\hline X2_7 & 112 & 2 & 5 & 3,94 & 0,852 \\
\hline X2_8 & 112 & 3 & 5 & 4,11 & 0,702 \\
\hline X2_9 & 112 & 2 & 5 & 4,03 & 0,765 \\
\hline X2_10 & 112 & 3 & 5 & 3,98 & 0,723 \\
\hline X2_11 & 112 & 2 & 5 & 4,00 & 0,827 \\
\hline X2_12 & 112 & 3 & 5 & 3,96 & 0,676 \\
\hline X2_13 & 112 & 2 & 5 & 4,03 & 0,607 \\
\hline X2_14 & 112 & 2 & 5 & 3,55 & 0,721 \\
\hline X2_15 & 112 & 3 & 5 & 3,86 & 0,642 \\
\hline X2_16 & 112 & 3 & 5 & 3,91 & 0,692 \\
\hline X2_17 & 112 & 3 & 5 & 3,92 & 0,646 \\
\hline XX2 & 112 & & & 3,99 & 0,71 \\
\hline Valid N (listwise) & 112 & & & & \\
\hline
\end{tabular}

Source: Data processed (2020)

Table 4.2 shows that the highest mean value is 4.36 , namely in the statement "easy to make cash payments" while the lowest mean value is in the statement "interior and exterior attractiveness level" which is 3.55. Overall, the average value of respondents' answers on the service quality variable is 3.99 , so it can be said that most of the respondents agree on this variable.

Table 4.3. Mean Value and Standard Deviation of Product Completeness

\begin{tabular}{|l|c|r|r|r|r|}
\hline \multicolumn{5}{|c|}{ Descriptive Statistics } \\
\hline & N & Minimum & Maximum & Mean & Std. Deviation \\
\hline X3_1 & 112 & 1 & 5 & 4,18 & 0,750 \\
\hline X3_2 & 112 & 2 & 5 & 4,16 & 0,800 \\
\hline
\end{tabular}




\begin{tabular}{|c|c|c|c|}
\hline$\Sigma \mathrm{X} 3$ & 112 & 4,17 & 0,78 \\
\hline Valid N (listwise) & 112 & & \\
\hline
\end{tabular}

Table 4.3 shows that the highest mean value is 4.18 , namely in the statement "there is a level of quality in the product" while the lowest mean value is in the statement "there are various types of goods needed by traders who are sold" which is 4.16. Overall, the average value of respondents' answers on the product completeness variable is 4.17 , so it can be said that most of the respondents agree on these variables.

Table 4.4. Mean Value and Standard Deviation of Customer Satisfaction

\begin{tabular}{|l|c|r|r|r|r|}
\hline \multicolumn{7}{|c|}{ Descriptive Statistics } \\
\hline & N & Minimum & Maximum & Mean & Std. Deviation \\
\hline Y_1 & 112 & 3 & 5 & 4,09 & 0,742 \\
\hline Y_2 & 112 & 3 & 5 & 4,01 & 0,741 \\
\hline Y_3 & 112 & 3 & 5 & 3,98 & 0,644 \\
$\Sigma Y$ & 112 & & & 4,03 & 0,71 \\
\hline Valid N (listwise) & 112 & & & & \\
\hline \multicolumn{7}{|c|}{ Source: Data processed (2020 }
\end{tabular}

Table 4.4 shows that the highest mean value is 4.09 , namely in the statement "level of desire to visit again" while the lowest mean value is in the statement "always provides input about quality" which is 3.98 . Overall, the customer satisfaction variable has a mean of 12.08 with a standard deviation of 2.005 , so it can be said that most of the respondents agree on this variable.

\subsection{Validity Test and Questionnaire Reliability Test}

\subsubsection{Questionnaire Validity Test}

The parameter used in this research is Pearson Correlation with sig. $<0.05$.

Table 4.5. Questionnaire Validity Test

\begin{tabular}{|c|c|c|c|c|}
\hline Variable & Code & Pearson & Sig. & Note. \\
\hline \multirow{5}{*}{ Product quality } & $\mathrm{X} 1 \_1$ & 0.780 & 0.000 & Valid \\
\hline & $\mathrm{X} 1 \_2$ & 0.851 & 0.000 & Valid \\
\hline & $\mathrm{X} 1 \_3$ & 0.215 & 0.023 & Valid \\
\hline & $\mathrm{X} 1 \_4$ & 0.785 & 0.000 & Valid \\
\hline & $\mathrm{X} 1 \_5$ & 0.689 & 0.000 & Valid \\
\hline \multirow{17}{*}{ Service Quality } & $\mathrm{X} 2 \_1$ & 0.883 & 0.000 & Valid \\
\hline & $\mathrm{X} 2 \_2$ & 0.746 & 0.000 & Valid \\
\hline & X2_3 & 0.564 & 0.000 & Valid \\
\hline & $\mathrm{X} 2 \_4$ & 0.853 & 0.000 & Valid \\
\hline & $\mathrm{X} 2 \_5$ & 0.735 & 0.000 & Valid \\
\hline & X2_6 & 0.759 & 0.000 & Valid \\
\hline & X2_7 & 0.743 & 0.000 & Valid \\
\hline & X2_8 & 0.858 & 0.000 & Valid \\
\hline & X2_9 & 0.720 & 0.000 & Valid \\
\hline & $\mathrm{X} 2 \_10$ & 0.851 & 0.000 & Valid \\
\hline & $\mathrm{X} 2 \_11$ & 0.705 & 0.000 & Valid \\
\hline & $\mathrm{X} 2 \_12$ & 0.887 & 0.000 & Valid \\
\hline & $\mathrm{X} 2 \_13$ & 0.630 & 0.000 & Valid \\
\hline & X2_14 & 0.338 & 0.000 & Valid \\
\hline & $\mathrm{X} 2 \_15$ & 0.662 & 0.000 & Valid \\
\hline & X2_16 & 0.733 & 0.000 & Valid \\
\hline & $\mathrm{X} 2 \_17$ & 0.813 & 0.000 & Valid \\
\hline \multirow{2}{*}{ Product Accessories } & X3_1 & 0.877 & 0.000 & Valid \\
\hline & X3_2 & 0.893 & 0.000 & Valid \\
\hline \multirow{3}{*}{ Customer satisfaction } & Y_1 & 0.964 & 0.000 & Valid \\
\hline & Y_2 & 0.951 & 0.000 & Valid \\
\hline & Y_3 & 0.909 & 0.000 & Valid \\
\hline
\end{tabular}

Source: Data processed (2020)

\subsubsection{Questionnaire Reliability Test}

The reliability parameter of a variable is if the value of Cronbach's Alpha >0.7. 
Table 4.6. Questionnaire Reliability Test

\begin{tabular}{|c|c|c|c|}
\hline Variable & Code & Pearson & Note. \\
\hline \multirow{5}{*}{ Product quality } & $\mathrm{X} 1 \_1$ & 0.750 & Reliable \\
\hline & $\mathrm{X} 1 \_2$ & 0.736 & Reliable \\
\hline & $\mathrm{X} 1 \_3$ & 0.817 & Reliable \\
\hline & $\mathrm{X} 1 \_4$ & 0.708 & Reliable \\
\hline & $\mathrm{X} 1 \_5$ & 0.728 & Reliable \\
\hline \multirow{17}{*}{ Service Quality } & $\mathrm{X} 2 \_1$ & 0.939 & Reliable \\
\hline & $\mathrm{X} 2 \_2$ & 0.943 & Reliable \\
\hline & $\mathrm{X} 2 \_3$ & 0.946 & Reliable \\
\hline & $\mathrm{X} 2 \_4$ & 0.940 & Reliable \\
\hline & $\mathrm{X} 2 \_5$ & 0.943 & Reliable \\
\hline & X2_6 & 0.942 & Reliable \\
\hline & $\mathrm{X} 2 \_7$ & 0.943 & Reliable \\
\hline & $\mathrm{X} 2 \_8$ & 0.940 & Reliable \\
\hline & X2_9 & 0.943 & Reliable \\
\hline & $\mathrm{X} 2 \_10$ & 0.940 & Reliable \\
\hline & $\mathrm{X} 2 \_11$ & 0.944 & Reliable \\
\hline & $\mathrm{X} 2 \_12$ & 0.940 & Reliable \\
\hline & $\mathrm{X} 2 \_13$ & 0.945 & Reliable \\
\hline & $\mathrm{X} 2 \_14$ & 0.951 & Reliable \\
\hline & $\mathrm{X} 2 \_15$ & 0.944 & Reliable \\
\hline & $\mathrm{X} 2 \_16$ & 0.943 & Reliable \\
\hline & $\mathrm{X} 2 \_17$ & 0.941 & Reliable \\
\hline \multirow{2}{*}{ Product Accessories } & X3_1 & 0.836 & Reliable \\
\hline & X3_2 & 0.828 & Reliable \\
\hline \multirow{3}{*}{ Customer satisfaction } & Y_1 & 0.868 & Reliable \\
\hline & Y_2 & 0.893 & Reliable \\
\hline & Y_3 & 0.947 & Reliable \\
\hline
\end{tabular}

\subsection{Classic assumption test}

\subsubsection{Outlier Test}

Detection of outliers is carried out using the Box and Whisker Plot technique or often referred to as the Boxplot. The boxplot has components including: (1) the smallest observation value, (2) the lowest quartile or first quartile (Q1) which cuts $25 \%$ of the lowest data, (3) the median (Q2) or the middle value, (4) the highest quartile or the third quartile (Q3) which cuts $25 \%$ of the highest data, and (5) the largest observation value. Here are the outlier test results:

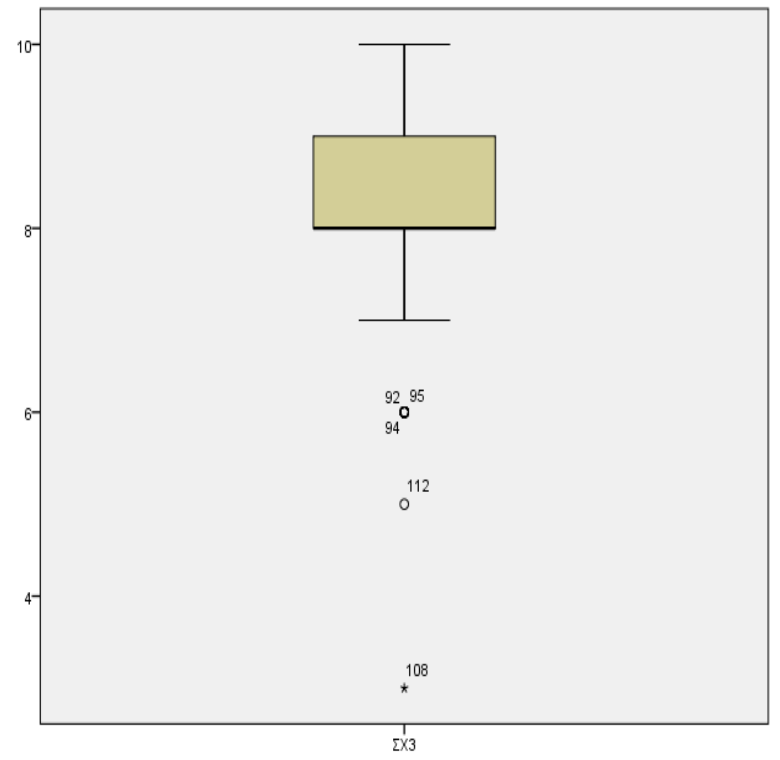

Figure 4.1. First Outlier Test Results Source: Data processed (2020) 
Observations categorized as outliers are the 92nd observation, 94th observation, 95th observation, 108th observation, and 112th observation. Based on this explanation, it is shown that the number of outlier data is 5 (five) data or observations, so the number of observations or data used for further testing is $112-5=107$ data or observations.

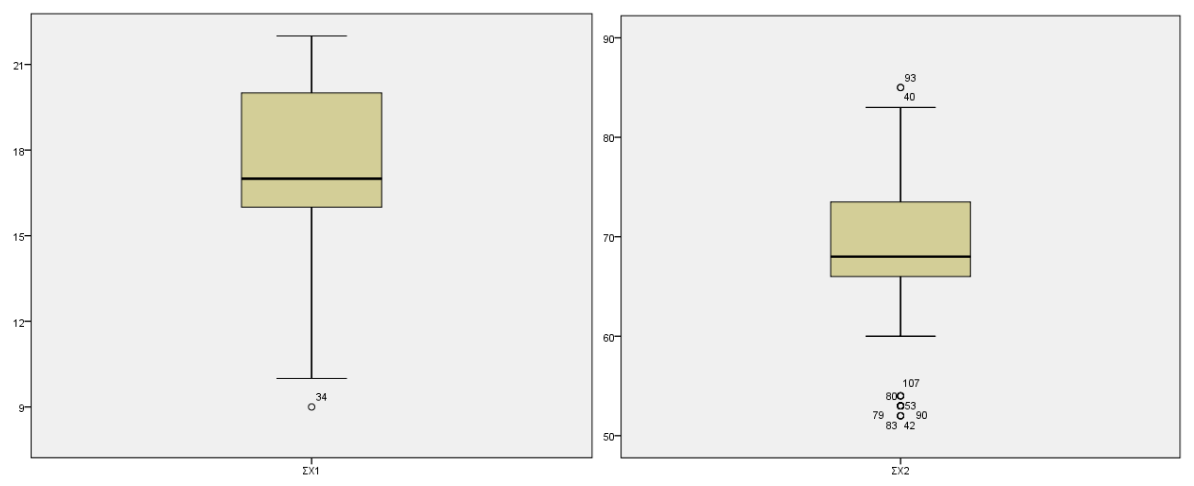

Figure 4.2. Second Outlier Test Results Source: Data processed (2020)

Based on the picture above, shows that the variable quality of the product $\left(\mathrm{X}_{1}\right)$ and the completeness of the product $\left(\mathrm{X}_{3}\right)$ there are outliers. Observations categorized as outliers are the 34th observation, 40th observation, 42nd observation, 53rd observation, 79th observation, 80th observation, 83rd observation, 90th observation, 93rd observation , and the 107th observation. Based on this explanation, it is shown that the number of outlier data is 10 (ten) data or observations, so that the number of observations or data used for further testing is $107-10=97$ data or observations.
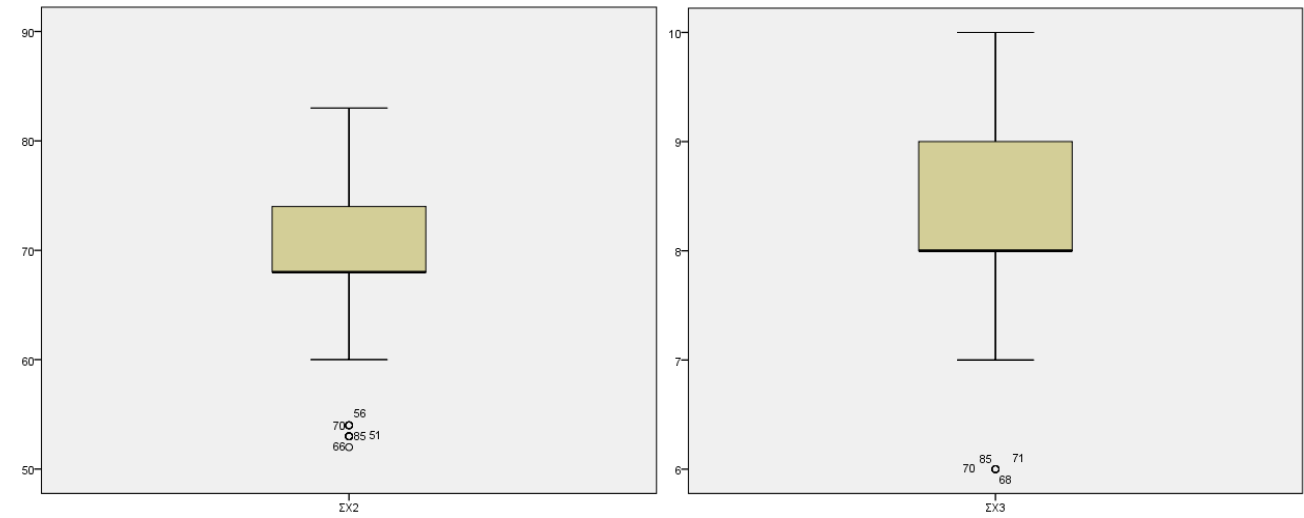

Figure 4.3. Third Outlier Test Results

Source: Data processed (2020)

Based on Figure 5.5 above, it shows that in the service quality variables $\left(\mathrm{X}_{2}\right)$ and product completeness $\left(\mathrm{X}_{3}\right)$ there are outliers. Observations categorized as outliers are the 51st observation, 56th observation, 66th observation, 68th observation, 70th observation, 71st observation, and 85th observation. Based on this explanation, it is shown that the number of outlier data is 7 (seven) data or observations, so that the number of observations or data used for further testing is $97-7=90$ data or observations.

\subsubsection{Normality test}

Table 4.7. Normality test

\begin{tabular}{|l|l|r|}
\hline \multicolumn{2}{|c|}{ One-Sample Kolmogorov-Smirnov Test } \\
\hline $\mathrm{N}$ & Unstandardized Residual \\
\hline Normal Parameters & \\
& Mean & 0,0000000 \\
\cline { 2 - 3 } & Std. Deviation & 0,95514904 \\
\hline \multirow{2}{*}{ Most Extreme Differences } & Absolute & 0,093 \\
\cline { 2 - 3 } & Positive & 0,077 \\
\cline { 2 - 3 } & Negative & $-0,093$ \\
\hline Test Statistic & 0,093 \\
\hline Asymp. Sig. (2-tailed) &, $053^{\mathrm{c}}$ \\
\hline a. Test distribution is Normal.
\end{tabular}


b. Calculated from data.
c. Lilliefors Significance Correction.

Source: Data processed (2020)

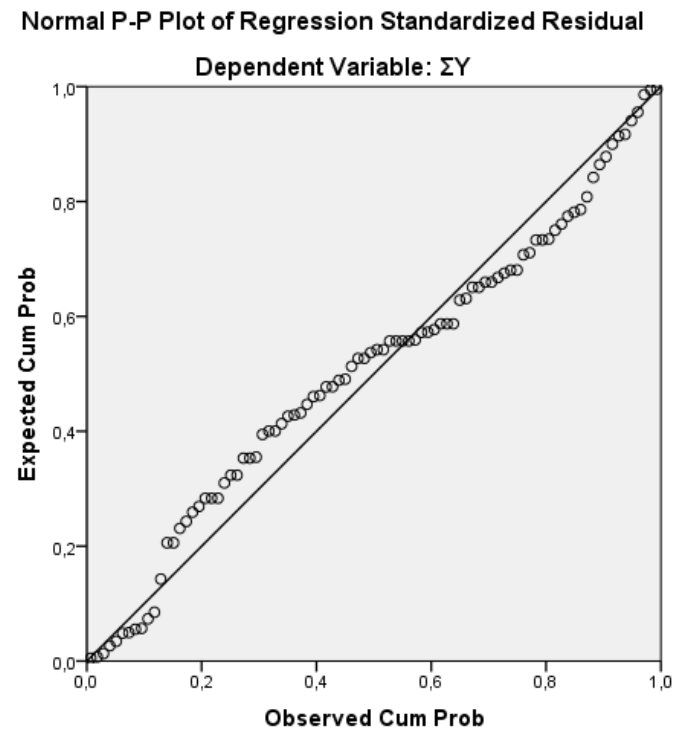

Figure 4.4. Normal PP Plot of Regression

Source: Data processed (2020)

Based on the above table it can be concluded that the distribution of data on the variable quality of the product $\left(\mathrm{X}_{1}\right)$, quality of service $\left(\mathrm{X}_{2}\right)$, the completeness of the product $\left(\mathrm{X}_{3}\right)$ and customer satisfaction $(\mathrm{Y})$ follows distribusinormal because of the significant value of the method of Kolmogorov-Smirnov greater than 0.05 which is 0.053. Based on the Normal P-Plot of Regression, it is known that the data spread on the diagonal source spreads around the line and follows the diagonal line, so the residual value is normal.

\subsubsection{Multicollinearity Test}

Table 4.8. Multicollinearity Test

\begin{tabular}{|c|c|c|c|c|c|c|c|c|}
\hline \multicolumn{9}{|c|}{ Coefficients $^{\mathrm{a}}$} \\
\hline & \multirow{2}{*}{ Model } & \multicolumn{2}{|c|}{ Unstandardized Coefficients } & \multirow{2}{*}{$\frac{\text { Standardized Coefficients }}{\text { Beta }}$} & \multirow{2}{*}{$\mathrm{T}$} & \multirow{2}{*}{ Sig. } & \multicolumn{2}{|c|}{ Collinearity Statistics } \\
\hline & & B & Std. Error & & & & Tolerance & VIF \\
\hline \multirow{4}{*}{1} & (Constant) & $-4,559$ & 1,332 & & $-3,423$ & 0,001 & & \\
\hline & $\Sigma \mathrm{X} 1$ & 0,037 & 0,038 & 0,060 & 0,978 & 0,331 & 0,922 & 1,085 \\
\hline & $\Sigma X 2$ & 0,195 & 0,016 & 0,770 & 12,452 & 0,000 & 0,913 & 1,096 \\
\hline & $\Sigma X 3$ & 0,311 & 0,109 & 0,172 & 2,844 & 0,006 & 0,960 & 1,042 \\
\hline
\end{tabular}

Source: Data processed (2020)

Based on the table above, it is known that the value of Tolerance and VIF of product quality variable $\left(\mathrm{X}_{1}\right)$ is 0.922 and 1.085; service quality variable $\left(\mathrm{X}_{2}\right)$ of 0.913 and 1.096; and the product completeness variable $\left(\mathrm{X}_{3}\right)$ is 0.960 and 1.042. So, it can be concluded that the three variables have a Tolerance value $>0.10$ and a VIF $<10$ meaning that they are free from multicollinearity symptoms.

\subsubsection{Heteroscedasticity Test}

Table 4.9. Heteroscedasticity Test

\begin{tabular}{|c|c|c|c|c|c|c|}
\hline \multicolumn{7}{|c|}{ Coefficients $^{\mathrm{a}}$} \\
\hline & \multirow{2}{*}{ Model } & \multicolumn{2}{|c|}{ Unstandardized Coefficients } & \multirow{2}{*}{$\frac{\text { Standardized Coefficients }}{\text { Beta }}$} & \multirow{2}{*}{$\mathrm{T}$} & \multirow{2}{*}{ Sig. } \\
\hline & & $\mathrm{B}$ & Std. Error & & & \\
\hline \multirow{4}{*}{1} & (Constant) & 0,626 & 0,898 & & 0,697 & 0,488 \\
\hline & $\Sigma X 1$ & $-0,019$ & 0,026 & $-0,084$ & $-0,756$ & 0,451 \\
\hline & $\Sigma X 2$ & 0,015 & 0,011 & 0,159 & 1,429 & 0,157 \\
\hline & $\Sigma X 3$ & $-0,075$ & 0,074 & $-0,111$ & $-1,022$ & 0,310 \\
\hline
\end{tabular}

Source: Data processed (2020)

Based on the table above, it is known that the value of sig. product quality variable $\left(\mathrm{X}_{1}\right)$ is 0.451 ; service quality variable $\left(\mathrm{X}_{2}\right)$ is 0.157 ; product completeness variable $\left(\mathrm{X}_{3}\right)$ is 0.310 . So, it can be concluded that the three 
variables have sig values. $>0.05$ means that it is free from heteroscedasticity symptoms or it can be said that there is an inequality of variance from the residuals for all observations in the regression model.

\subsection{Multiple Linear Regression Analysis}

Table 4.10. Multiple Linear Regression Analysis

\begin{tabular}{|c|c|c|c|c|c|c|}
\hline \multicolumn{7}{|c|}{ Coefficients $\mathrm{a}$} \\
\hline & \multirow{2}{*}{ Model } & \multicolumn{2}{|c|}{ Unstandardized Coefficients } & \multirow{2}{*}{$\frac{\text { Standardized Coefficients }}{\text { Beta }}$} & \multirow{2}{*}{$\mathrm{t}$} & \multirow{2}{*}{ Sig. } \\
\hline & & B & Std. Error & & & \\
\hline \multirow{4}{*}{1} & (Constant) & $-4,559$ & 1,332 & & $-3,423$ & 0,001 \\
\hline & $\Sigma \mathrm{X} 1$ & 0,037 & 0,038 & 0,060 & 0,978 & 0,331 \\
\hline & $\Sigma \mathrm{X} 2$ & 0,195 & 0,016 & 0,770 & 12,452 & 0,000 \\
\hline & $\Sigma X 3$ & 0,311 & 0,109 & 0,172 & 2,844 & 0,006 \\
\hline & Feciot & $\Sigma Y$ & & & & \\
\hline
\end{tabular}

Source: Data processed (2020)

Based on the table above, the equation is

$$
\mathrm{Y}=-4,559+0,037 \mathrm{X} 1+0,195 \mathrm{X} 2+0,311 \mathrm{X} 3 .
$$

According to this equation, it can be seen that:

1. The resulting constant is -4.559 , which means that if the variables of product quality $\left(\mathrm{X}_{1}\right)$, service quality $\left(\mathrm{X}_{2}\right)$, and product completeness $\left(\mathrm{X}_{3}\right)$ are zero, the constant value $(\alpha)$ is -4.559 .

2. The regression coefficient for the product quality variable $\left(\mathrm{X}_{1}\right)$ is 0.037 which means it can be explained that every 1 (one) unit change in the value of the product quality variable $\left(\mathrm{X}_{1}\right)$ will increase customer satisfaction $(\mathrm{Y})$ by 0.037 units assuming service quality $\left(\mathrm{X}_{2}\right)$ and the completeness of the product $\left(\mathrm{X}_{3}\right)$ is constant.

3. The regression coefficient for the variable quality of service $\left(X_{2}\right)$ is 0.195 which means it can be explained that for every 1 (one) unit change in the value of the variable quality of service $\left(\mathrm{X}_{2}\right)$ will increase customer satisfaction $(\mathrm{Y}) 0.195$ units assuming the quality of the product $\left(\mathrm{X}_{1}\right)$ and the completeness of the product $\left(\mathrm{X}_{3}\right)$ are constant.

4. The regression coefficient for the product completeness variable $\left(\mathrm{X}_{3}\right)$ is 0.311 which means it can be explained that every 1 (one) unit change in the value of the product completeness variable $\left(\mathrm{X}_{3}\right)$ will increase customer satisfaction $(\mathrm{Y})$ by 0.311 units assuming product quality $\left(\mathrm{X}_{1}\right)$ and the quality of service $\left(\mathrm{X}_{2}\right)$ is constant.

\subsection{Hypothesis testing}

\subsubsection{Simultaneous Significance Test (F Test)}

In connection with the opinion of Siregar (2013) if the significance value of $F<0.05$ means that the independent variables jointly have a significant effect on the dependent variable.

Table 4.11. Simultaneous Significance Test (F Test)

\begin{tabular}{|l|l|r|r|r|c|c|}
\hline \multicolumn{7}{|c|}{ ANOVA $^{\mathrm{a}}$} \\
\hline \multirow{2}{|c|}{ Model } & Sum of Squares & Df & Mean Square & F & Sig. \\
\hline \multirow{2}{*}{1} & Regression & 189,027 & 3 & 63,009 & 66,737 &, $000^{\mathrm{b}}$ \\
& Residual & 81,196 & 86 & 0,944 & & \\
\cline { 2 - 6 } & Total & 270,222 & 89 & & & \\
\hline \multicolumn{2}{|l}{ a. Dependent Variable: $\Sigma Y$} \\
\hline
\end{tabular}

Source: Data processed (2020)

The test uses a significance level of $<0.05$. Based on the table above, obtained a significance of 0.000 or $<0.05$, it can be stated that the variables of product quality $\left(\mathrm{X}_{1}\right)$, service quality $\left(\mathrm{X}_{2}\right)$, and product completeness $\left(\mathrm{X}_{3}\right)$ simultaneously have a simultaneous effect on customer satisfaction ( $\mathrm{Y}$ ).

\subsubsection{Partial Significance Test ( $t$ Test)}

Table 4.12. Partial Significance Test (t Test)

\begin{tabular}{|c|c|c|c|c|c|c|}
\hline \multicolumn{7}{|c|}{ Coefficients $^{\mathrm{a}}$} \\
\hline & \multirow{2}{*}{ Model } & \multicolumn{2}{|c|}{ Unstandardized Coefficients } & \multirow{2}{*}{$\frac{\text { Standardized Coefficients }}{\text { Beta }}$} & \multirow{2}{*}{$\mathrm{T}$} & \multirow{2}{*}{ Sig. } \\
\hline & & B & Std. Error & & & \\
\hline \multirow{2}{*}{1} & (Constant) & $-4,559$ & 1,332 & & $-3,423$ & 0,001 \\
\hline & $\Sigma X 1$ & 0,037 & 0,038 & 0,060 & 0,978 & 0,331 \\
\hline
\end{tabular}




\begin{tabular}{|l|r|r|r|r|r|}
\hline$\Sigma X 2$ & 0,195 & 0,016 & 0,770 & 12,452 & 0,000 \\
\hline$\Sigma X 3$ & 0,311 & 0,109 & 0,172 & 2,844 & 0,006 \\
\hline
\end{tabular}

Source: Data processed (2020)

Based on the table above, the significance value for the product quality variable $\left(\mathrm{X}_{1}\right)$ is 0.331 or $>$ 0.05 ; service quality variable $\left(\mathrm{X}_{2}\right)$ is 0.000 or $<0.05$; and the product completeness variable $\left(\mathrm{X}_{3}\right)$ is $0.006<$ 0.05 . Thus, it can be stated that the variable quality of the product $\left(\mathrm{X}-{ }_{1}\right)$ had no effect partially on satisfaction variable customers $(\mathrm{Y})$ or $\mathrm{H}_{1}$ is rejected, the variable quality of service $\left(\mathrm{X}_{2}\right)$ partial effect to variable customer satisfaction $(\mathrm{Y})$ or $\mathrm{H}_{2}$ is received, and the variable range of products $\left(\mathrm{X}_{3}\right)$ partial effect on customer satisfaction variable (Y) or $\mathrm{H}_{3}$ received.

\subsubsection{Coefficient of Determination Test $\left(R^{2}\right)$ and Relationship Coefficient Test $(r)$}

Table 4.13. Coefficient of Determination Test $\left(\mathrm{R}_{2}\right)$ and Relationship Coefficient Test ( $\mathrm{r}$ )

\begin{tabular}{|c|c|r|r|r|}
\hline \multicolumn{5}{|c|}{ Model Summary } \\
\hline Model & $\mathrm{R}$ & R Square & Adjusted R Square & Std. Error of the Estimate \\
\hline 1 &, $836^{\mathrm{a}}$ & 0,700 & 0,689 & 0,972 \\
\hline a. Predictors: (Constant), $\Sigma X 3, \Sigma X 1, \Sigma X 2$ \\
\hline \multicolumn{6}{|c|}{ Source: Data processed (2020) }
\end{tabular}

Based on the above table mentioned that the value of $\mathrm{R}^{2}$ by 0,700 or $70 \%$ means that the influence of the variable quality of the product $\left(\mathrm{X}_{1}\right)$, quality of service $\left(\mathrm{X}_{2}\right)$, and the completeness of the product $\left(\mathrm{X}_{3}\right)$ by $70 \%$ while the rest influenced by other variables.

\section{Conclusions and Practical Implication}

\subsection{Conclusion}

Product quality has no effect on customer satisfaction at the Mie Soponyono producer so that hypothesis 1 is rejected. This is probably due to the fact that the price of the goods tends to be cheap and the goods are for resale where the noodle product which will be cooked will be more influenced by the combination of other spices, so in this case the quality of the product has no effect on customer satisfaction. The results of this study are directly proportional to the research conducted by Budiastari (2017) which states that product quality has no effect on customer satisfaction. Conditions at the time of the research conducted by Budiastari (2017), the price offered by Holcim tends to be the highest when compared to its competitors.

Service quality has an effect on customer satisfaction at Mie Soponyono producers so that hypothesis 2 is accepted. This proves that the quality of service provided by the Mie Soponyono producer is good, the better the quality of the service provided, the higher the customer satisfaction at the Mie Soponyono producer, and vice versa the low service quality will affect the decrease in customer satisfaction. The results of this study are directly proportional to the research conducted by Sembiring et al. (2014) and Haryanto (2013) which state that service quality affects customer satisfaction.

Completeness of the product has an effect on customer satisfaction at the Mie Soponyono Producer. This proves that the completeness of the product is sufficient to meet customer needs, the higher the completeness of the product, the higher the customer satisfaction at Mie Soponyono Manufacturers. The results of this study are directly proportional to the research conducted by Herlina (2018) which states that the completeness of the product has an effect on customer satisfaction. This shows that the more complete the products offered by Indomaret Bandung, the higher the level of consumers who decide to shop at Indomaret Bandung. The variables of product quality, service quality and product completeness contribute to the influence of customer satisfaction by $70 \%$, while the rest is influenced by other variables.

\subsection{Practical Implication}

Table 5.1. Managerial Implications

\begin{tabular}{|c|c|c|}
\hline Variable & Before Research & Managerial Implications \\
\hline Product quality & $\begin{array}{l}\text { 1. The attractiveness of product } \\
\text { presentation is still low }\end{array}$ & $\begin{array}{l}\text { 1. research the attractiveness of attractive presentations from } \\
\text { 2. several existing competitors } \\
\text { 3. choose packaging that fits the criteria }\end{array}$ \\
\hline
\end{tabular}




\begin{tabular}{|l|l|l|l|}
\hline Service quality & $1 . \quad \begin{array}{l}\text { The level of attractiveness of the interior } \\
\text { and exterior }\end{array}$ & $\begin{array}{l}1 . \\
2 .\end{array}$ & $\begin{array}{l}\text { Doing checks and checks about the interior and exterior } \\
\text { Doing sorting which is lacking from interior and exterior } \\
\text { Details which can be done first based on the deadline for the } \\
\text { work that can be done first }\end{array}$ \\
\hline $\begin{array}{l}\text { Product } \\
\text { Accessories }\end{array}$ & 1. & $\begin{array}{l}\text { There are various types of goods that } \\
\text { traders need for sale }\end{array}$ & $\begin{array}{l}\text { 1. } \\
\text { accommodate product searches that consumers are looking for } \\
\text { but there are no products }\end{array}$ \\
& 2. & $\begin{array}{l}\text { Assess how high the search rate for the product is } \\
\text { Researching which of our products have high sales and which } \\
\text { are not } \\
\text { Doing product addition or not and product degradation or not } \\
\text { in accordance with the assessment }\end{array}$ \\
\hline
\end{tabular}

\section{References}

Anshori, Y., \& Langner, V. (2007). The importance of customer satisfaction and supreme service provision in the hotel industry: a case study of Surabaya Plaza Hotel. Jurnal Manajemen Perhotelan, 3(1), 18-25. https://doi.org/10.9744/jmp.3.1.18-25

Atmawati, R., \& Wahyuddin, M. (2004). Analisis pengaruh kualitas pelayanan terhadap kepuasan konsumen pada Matahari Departement Store di Solo Grand Mall. Jurnal Ekonomi Manajemen Sumber Daya, 5(1), 54-61.

Budiastari, S. (2017). Pengaruh kualitas produk, persepsi harga, dan citra merek terhadap kepuasan dan loyalitas pelanggan beton siap pakai Holcim di Jakarta. Jurnal Dinamika Manajemen Dan Bisinis, 1(1), 87-106. https://doi.org/10.21009/JDMB.01.1.4

Gilbert, D. (2003). Retail marketing management. New Jersey: Prentice Hall.

Haryanto, R. A. (2013). Strategi promosi, kualitas produk, kualitas layanan terhadap kepuasan pelanggan pada restoran McDonald's Manado. Jurnal Riset Ekonomi, Manajemen, Bisnis Dan Akuntansi, 1(4), 1465-1473. https://doi.org/https://doi.org/10.35794/emba.1.4.2013.2923

Herlina. (2018). Analisis pengaruh harga dan kelengkapan produk terhadap keputusan pembelian serta dampaknya pada kepuasan konsumen. Isu Teknologi STT Mandala, 13(2), 108-123.

Kotler, P. (2002). Manajemen Pemasaran. Jilid 2 (Jakarta: PT Prenhallindo (ed.); Millenium).

Kotler, P., \& Amstrong, G. (2016). Principles of marketing (16th ed.). New Jersey : Pearson Prentince Hall.

Kotler, P., \& Armstrong, G. (2010). Principles of marketing (13th ed.). New Jersey Pearson education.

Kotler, P., \& Keller, K. L. (2012). Manajemen pemasaran. Jilid 1 (12nd ed.). Jakarta: Erlangga.

Lupiyoadi, R. (2001). Manajemen pemasaran jasa. Jakarta: Salemba Empat.

Mulyono, B. H., Yoestini, Nugraheni, R., \& Kamal, M. (2007). Analisis pengaruh kualitas produk dan kualitas layanan terhadap kepuasan konsumen (Studi kasus pada Perumahan Puri Mediterania Semarang). Jurnal Studi Manajemen Organisasi, 4(2), 91-100.

Nur Prabowo, W. (2015). Pengaruh harga, promosi, lokasi, kelengkapan produk dan kualitas pelayanan terhadap kepuasan konsumen (Studi empiris pada konsumen Indomaret di Kabupaten Karanganyar). Universitas Muhammadiyah Surakarta.

Pertiwi, E. L. (2017). The Effect Of Product Quality, Completeness Of Product and Service Quality to Customer Satisfaction "Yulia Bakery" Kota Kediri. Simki-Economic, 1(11), 1-16.

Priyatno, D. (2014). Mandiri belajar dnalisis Data dengan SPSS. Yogyakarta: Mediakom.

Sembiring, I. J. (2014). Pengaruh kualitas produk dan kualitas pelayanan terhadap kepuasan pelanggan dalam membentuk loyalitas pelanggan (Studi pada pelanggan McDonald's MT. Haryono Malang). Universitas Brawijaya.

Siregar, S. (2013). Metode penelitian kuantitatif. Jakarta: Prenadamedia Group. 
Sugiyono. (2012). Statistika untuk penelitian. Bandung: Alfabeta.

Sujarweni, V. W. (2016). Metode penelitian: Lengkap, praktis, dan mudah Dipahami. Yogyakarta: Pustaka Baru Press.

Sunyoto, D. (2009). Analisis regresi dan uji hipotesis. Yogyakarta: Buku Tunggal.

Tjiptono, F., \& Chandra, G. (2011). Service, quality, \& satisfaction (3rd ed.). Yogyakarta : Andi.

Tjiptono, Fandy. (2008). Strategi pemasaran (Edisi 3). Yogyakarta: CV. Andi Offset.

Tjiptono, Fandy. (2009). Strategi pemasaran jasa. Yogyakarta: Andi. 